\title{
Corrosion Study of Cr-Oxide Ceramics Using Rotating Ring Disk Electrode
}

\author{
Fenini, Filippo; Kammer Hansen, Kent; Mogensen, Mogens Bjerg
}

Published in:

Journal of The Electrochemical Society

Link to article, DOI:

10.1149/2.0191911jes

Publication date:

2019

Document Version

Publisher's PDF, also known as Version of record

Link back to DTU Orbit

Citation (APA):

Fenini, F., Kammer Hansen, K., \& Mogensen, M. B. (2019). Corrosion Study of Cr-Oxide Ceramics Using Rotating Ring Disk Electrode. Journal of The Electrochemical Society, 166(11), C3159-C3169.

https://doi.org/10.1149/2.0191911jes

\section{General rights}

Copyright and moral rights for the publications made accessible in the public portal are retained by the authors and/or other copyright owners and it is a condition of accessing publications that users recognise and abide by the legal requirements associated with these rights.

- Users may download and print one copy of any publication from the public portal for the purpose of private study or research.

- You may not further distribute the material or use it for any profit-making activity or commercial gain

- You may freely distribute the URL identifying the publication in the public portal

If you believe that this document breaches copyright please contact us providing details, and we will remove access to the work immediately and investigate your claim. 


\title{
ECSS \\ JES Focus Issue on Electrochemical Techniques in Corrosion Science in Memory of Hugh IsaAcs \\ Corrosion Study of Cr-Oxide Ceramics Using Rotating Ring Disk Electrode
}

\author{
Filippo Fenini, $\oplus^{*, z}$ Kent Kammer Hansen, $\bullet$ and Mogens Bjerg Mogensen $\oplus^{* * *}$ \\ Department of Energy Conversion and Storage, Technical University of Denmark, 4000 Roskilde, Denmark
}

\begin{abstract}
Proton Exchange Membrane Electrolysis demands new resistant and cheap materials for the anode components, and Cr-based spinels are acid stable ceramics, which may meet the requirements of such application to some extent. This work reports the electrochemical behavior of spinel-structured $\mathrm{MnCu}_{0.25} \mathrm{Cr}_{1.75} \mathrm{O}_{4}$ and $\mathrm{NiCr}_{2} \mathrm{O}_{4}$ up to $2.0 \mathrm{~V}$ in order to determine the stability/dissolution of such materials when exposed to anodic potential. The ceramic/graphite composite was deposited on a rotating ring disk electrode and scanned while the ring electrode was held at $0.5 \mathrm{~V}$ vs SHE. The dissolution of $\mathrm{Cr}$ species was observed to happen as the oxidation proceeded by collecting the dissolved products at the ring electrode. $\mathrm{HCrO}_{4}{ }^{-}$and $\mathrm{MnO}_{4}{ }^{-}$were identified as dissolved products. Analysis of post-test solutions, revealed the difference between chemical and electrochemical corrosion of the materials.

(C) The Author(s) 2019. Published by ECS. This is an open access article distributed under the terms of the Creative Commons Attribution Non-Commercial No Derivatives 4.0 License (CC BY-NC-ND, http://creativecommons.org/licenses/by-nc-nd/4.0/), which permits non-commercial reuse, distribution, and reproduction in any medium, provided the original work is not changed in any way and is properly cited. For permission for commercial reuse, please email: oa @ electrochem.org. [DOI: 10.1149/2.0191911jes]
\end{abstract}

Manuscript submitted February 20, 2019; revised manuscript received April 14, 2019. Published April 26, 2019. This paper is part of the JES Focus Issue on Electrochemical Techniques in Corrosion Science in Memory of Hugh Isaacs.

Proton Exchange Membrane Electrolysis Cells (PEMECs) encompass the key features required for a renewable electricity driven energy conversion device (such as high current density, broad dynamic range, high product purity, fast system response and short start-up time) with unmatched completeness among electrolysis technologies. ${ }^{1}$ They are currently in the commercialization stage, even if limited to small and medium sized units. ${ }^{2}$ The main reason is the high capital cost compared with the more mature technology of alkaline electrolysis (the latter requires half the capital compared to PEMECs technology). ${ }^{1}$ On a stack level, the costs are dominated by Membrane-Electrode Assemblies (MEAs) and current collectors. In both cases, the cost-driving compartment of a PEMEC is the anode compartment, in which the materials are exposed to very strong oxidizing conditions. In the case of the MEA, the loadings of $\mathrm{IrO}_{2}$, which the state-of-the-art oxygen evolution reaction (OER) catalyst, is usually 5-10 times higher than the loading of the more abundant element, Pt, which is the state-ofthe-art hydrogen evolution reaction (HER) catalyst. ${ }^{3}$ Reduction of the $\mathrm{IrO}_{2}$ loading is possible, but it may require noble-metal coating of the current collector surface, which supports the OER catalyst. In fact, in the case of OER, no catalyst support, which can withstand the harsh conditions at the anode, is currently available for commercial stacks, and high $\mathrm{IrO}_{2}$ loadings are required to achieve sufficiently high current density. The very oxidizing conditions demand the use of a valve metal such as Ti to avoid critical degradation of the components including the bipolar plate. Noble-metal coatings are anyway employed in practical application, but they showed nevertheless to degrade under high anodic potential (high current density) operation. ${ }^{4}$ The need for new inexpensive, stable materials for the technology is pressing. In the case of MEAs, a robust catalyst support means a better catalyst utilization, which can increase substantially the current per unit weight of catalyst, and many indications are reported of beneficial interaction between catalyst and support, both in terms of stability and activity ${ }^{5-8}$ in the case of the hardware, non-Ti based current collectors and bipolar plates are very appealing because of lower cost and easier manufacturing, and corrosion-resistant coatings and materials are extensively researched. ${ }^{9-12}$

Chromites spinels are known to be extremely stable compounds even at high temperatures. They have been investigated as refractory materials ${ }^{13}$ and as interconnect coatings in solid oxide fuel cells. ${ }^{14-18}$

\footnotetext{
*Electrochemical Society Student Member.

**Electrochemical Society Fellow.

${ }^{\text {z} E-m a i l: ~ f f e n i n i @ e n g . a u . d k ~}$
}

Iron-chromium-nickel spinels are widely reported to constitute the corrosion product of stainless steels. ${ }^{19-22}$ They showed excellent corrosion resistance even in very harsh conditions, ${ }^{23}$ consequently they have been considered interesting candidates as corrosion resistant ceramics for the intended application. In our previous study, ${ }^{24}$ their corrosion stability in acidic environment has been assessed. Nonetheless, in real cell operation the materials could experience even harsher conditions due to the applied potential. This study constitutes a further characterization of the materials which exhibited the best electrical conductivity among the studied spinel chromites, namely $\mathrm{MnCu}_{0.25} \mathrm{Cr}_{1.75} \mathrm{O}_{4}$ and $\mathrm{NiCr}_{2} \mathrm{O}_{4}$.

\section{Electrochemistry of Ceramic Compounds}

To get insight into the electrochemical behavior of a complex compound, it is possible to look at the behavior of similar compounds where only one of the elements of the complex material is present at a time. In the case of spinel $\mathrm{MCr}_{2} \mathrm{O}_{4}$ (where $\mathrm{M}$ can be any metal with oxidation state II), this means that we can expect that the electrochemical features of the spinel will resemble the behavior of $\mathrm{Cr}_{2} \mathrm{O}_{3}$ and MO combined. Sedano et al. demonstrated that the characteristic features of $\mathrm{Cu}$ and $\mathrm{Fe}$ single oxides are also present in copper ferrites. ${ }^{25}$ Moreover, Grygar et al. showed that, for the system $\mathrm{Fe}_{2} \mathrm{O}_{3}-\mathrm{Mn}_{2} \mathrm{O}_{3}$, the variation of electrochemical response followed the change in composition of the solid solution. ${ }^{26}$

$\boldsymbol{C r}$ (III) oxides.- $\mathrm{Cr}$ (III) oxides undergo oxidative dissolution via a multiple-steps process, which is represented in the scheme on the top of Figure $1 .{ }^{27} \mathrm{Cr}$ (III) on the surface of the $\mathrm{Cr}$ oxides is firstly oxidized to $\mathrm{Cr}(\mathrm{IV})$ which can either be further oxidized to $\mathrm{Cr}(\mathrm{V})$ or disproportionate to give $\mathrm{Cr}(\mathrm{III})$ and $\mathrm{CrO}_{4}{ }^{2-}$ in aqueous environment. $\mathrm{Cr}(\mathrm{V})$ then dissolves after oxidation to $\mathrm{CrO}_{4}{ }^{2-}$. $\mathrm{CrO}_{4}{ }^{2-}$ is mostly protonated at the $\mathrm{pH}$ of $0.5 \mathrm{M} \mathrm{H}_{2} \mathrm{SO}_{4}(\mathrm{pH}=0.36)$, which is the solution used for conducting electrochemical characterization (see Figure 1). The reduction of $\mathrm{HCrO}_{4}{ }^{-}$proceeds as ${ }^{28}$

$$
\begin{gathered}
\mathrm{HCrO}_{4}^{-}+7 \mathrm{H}^{+}+3 \mathrm{e}^{-} \rightleftharpoons \mathrm{Cr}^{3+}+4 \mathrm{H}_{2} \mathrm{O} \\
E^{o}=1.38 \mathrm{~V} \text { vs SHE }
\end{gathered}
$$

Chromic acid is in equilibrium with dichromate ion in solution, so the reduction can also proceed according to

$$
2 \mathrm{HCrO}_{4}^{-} \rightleftharpoons \mathrm{Cr}_{2} \mathrm{O}_{7}^{2-}+\mathrm{H}_{2} \mathrm{O}
$$



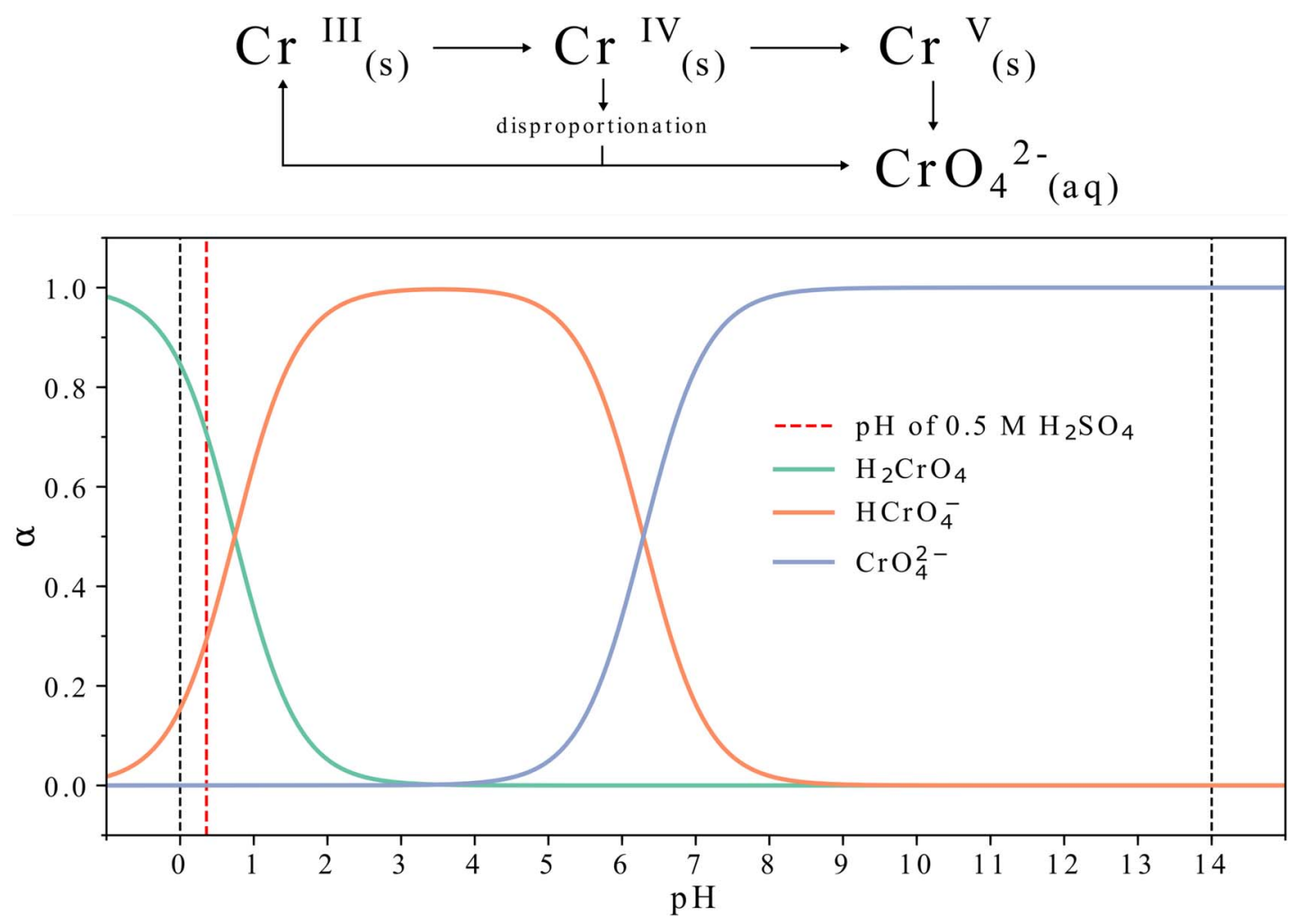

Figure 1. (top) Reaction scheme of Cr oxidation in aqueous environment as reported in Ref. 26, where $s$ and aq indicate solid state and aqueous species respectively; (bottom): Fraction $\alpha$ of chromic acid species as a function of $\mathrm{pH}$ in aqueous environment; the values of the dissociation constants used for the calculations were taken from Rumble. ${ }^{33}$

$$
\begin{gathered}
\mathrm{Cr}_{2} \mathrm{O}_{7}{ }^{2-}+14 \mathrm{H}^{+}+6 \mathrm{e}^{-} \rightleftharpoons 2 \mathrm{Cr}^{3+}+7 \mathrm{H}_{2} \mathrm{O} \\
E^{o}=1.36 \mathrm{~V} \text { vs SHE }
\end{gathered}
$$

The two reactions are iso-electronic for the same moles of starting chromium reagent, and they are very close in equilibrium potentials.

Mn oxides. $-\mathrm{Mn}(\mathrm{II})$ ions are oxidized to $\mathrm{MnO}_{2}$ at potentials $>1.4 \mathrm{~V}$ vs SHE. ${ }^{29} \mathrm{Mn}$ (III,IV) oxides are reported to undergo reductive dissolution when scanned negatively from high to low potentials. ${ }^{30} \mathrm{Ox}$ idation of $\mathrm{Mn}(\mathrm{IV})$ in $\mathrm{MnO}_{2}$ to higher valences in alkaline aqueous solution has been reported to form soluble species (such as permanganates ions). ${ }^{31,32}$ Permanganate ion can be reduced in acid environment, ${ }^{28}$ according to Equation 4:

$$
\begin{gathered}
\mathrm{MnO}_{4}{ }^{-}+4 \mathrm{H}^{+}+3 \mathrm{e}^{-} \rightleftharpoons \mathrm{MnO}_{2}+2 \mathrm{H}_{2} \mathrm{O} \\
\mathrm{E}^{\mathrm{o}}=1.70 \mathrm{~V} \text { vs SHE }
\end{gathered}
$$

$\mathrm{Ni}$ oxides.- $\mathrm{NiO}$ is reported to generate two symmetrical peaks when cycled in $0.5 \mathrm{M} \mathrm{H}_{2} \mathrm{SO}_{4}{ }^{34} \mathrm{~A}$ first peak is present at $1.0 \mathrm{~V}$ vs SHE, corresponding to the oxidation $\mathrm{Ni}(\mathrm{II}) / \mathrm{Ni}(\mathrm{III})$. A second peak centered at $1.4 \mathrm{~V}$ vs SHE has been attributed to the oxidation $\mathrm{Ni}(\mathrm{III}) / \mathrm{Ni}(\mathrm{IV})$. Bonomo et al. ${ }^{35}$ studied the dissolution of tape cast $\mathrm{NiO}$ electrodes in $\mathrm{KH}_{2} \mathrm{PO}_{4} / \mathrm{K}_{2} \mathrm{HPO}_{4}$ buffer, showing the same reversible peaks as in, ${ }^{34}$ even if at different potentials because of different $\mathrm{pH}$. They attribute the two peaks to the following reactions of hydrated $\mathrm{NiO}$

$$
\mathrm{NiO}\left(\mathrm{H}_{2} \mathrm{O}\right)_{\mathrm{p}} \rightleftharpoons \mathrm{NiO}(\mathrm{OH})\left(\mathrm{H}_{2} \mathrm{O}\right)_{\mathrm{p}-1}+\mathrm{H}^{+}+\mathrm{e}^{-}
$$

$$
\mathrm{NiO}(\mathrm{OH})\left(\mathrm{H}_{2} \mathrm{O}\right)_{\mathrm{p}-1} \rightleftharpoons \mathrm{NiO}(\mathrm{OH})_{2}\left(\mathrm{H}_{2} \mathrm{O}\right)_{\mathrm{p}-2}+\mathrm{H}^{+}+\mathrm{e}^{-}
$$

They also report that the layer undergoes important dissolution upon cycling.
Cu oxides.-The most common oxidation states of $\mathrm{Cu}$ are $\mathrm{Cu}$ (II) and $\mathrm{Cu}(\mathrm{I}) \cdot \mathrm{Cu}_{2} \mathrm{O}$ and $\mathrm{CuO}$ can be reduced at potentials below $0.5 \mathrm{~V}$ vs SHE. ${ }^{25} \mathrm{Cu}$ (III) is not a common oxidation state of $\mathrm{Cu}$ in aqueous solutions. In the solid state, examples of the existence of $\mathrm{Cu}$ (III) are scarce with a prominent example being the superconducting cuprates, where it is thought that $\mathrm{Cu}$ (III) $\mathrm{Cu}$ (II)ratio plays a key role in the superconducting properties of the materials. ${ }^{36} \mathrm{Cu}(\mathrm{III})$ is stable in solution only as a complex, ${ }^{37}$ otherwise it is unstable in aqueous solution. ${ }^{28}$

\section{Experimental}

Electrode preparation.- The Cr-based spinels with composition $\mathrm{MnCu}_{0.25} \mathrm{Cr}_{1.75} \mathrm{O}_{4}$ and $\mathrm{NiCr}_{2} \mathrm{O}_{4}$ were prepared by nitrate combustion synthesis. Prior to electrochemical characterization, the materials were also tested toward chemical corrosion by immersion in an acid mixture 1:1 of $1 \mathrm{M} \mathrm{H}_{2} \mathrm{SO}_{4}$ and $1 \mathrm{M} \mathrm{HNO}_{3}$ acid. The mass loss due to chemical dissolution was used to assess the stability of the materials toward acid corrosion. The details of the synthesis and the characterization conducted are reported elsewhere. ${ }^{24,38}$ The materials were deposited by ink-drop casting ${ }^{39}$ on rotating ring-disk electrodes (RRDE) with glassy carbon disk and $\mathrm{Pt}$ ring $\left(\mathrm{A}_{\mathrm{DISK}}\right.$ : 0.196 and $0.243 \mathrm{~cm}^{2} ; \mathrm{A}_{\mathrm{RING}}$ : 0.110 and $0.169 \mathrm{~cm}^{2}$; collection efficiency: 0.26 and 0.38 , Pine Research Instrumentation). Before each deposition, the surface of the RRDE was polished to a mirror finish on a moistened polishing microcloth using alumina powder of progressively smaller particle size $(1,0.3,0.05 \mu \mathrm{m}$, Buehler). For the preparation of the inks, the average size of the ceramic particles was reduced by ball milling with $\mathrm{ZrO}_{2}$ cylinders (h: $9 \mathrm{~mm}$, Ø: $5 \mathrm{~mm}$ ) for five days. Ceramic materials with low conductivity can be non-trivial to characterize electrochemically. A classical approach ${ }^{25,40,41}$ is to mix the material of interest with a conductive yet electrochemically inactive matrix (such as carbonaceous materials) which can guarantee sufficient electrical contact without contributing substantially to the measured current. Using this 
approach, in this study, a mixture of ceramic material and graphite was prepared as follows: an ink with a total ceramic loading of $2.5 \mathrm{mg}$ $\mathrm{ml}^{-1}$ was prepared by mixing equal amounts of a $5 \mathrm{mg} \mathrm{ml}^{-1}$ suspension of ceramic material in ethanol (Ethanol absolute $\geq 99.8 \%$, VWR) and a $5 \mathrm{mg} \mathrm{ml}^{-1}$ suspension of graphite in 2-propanol (graphite: $>99 \%$, particle size $<20 \mu \mathrm{m}$, Fluka; 2-propanol: anhydrous, 99.5\%, Sigma Aldrich) previously sonicated for 5 minutes. The mixture was further sonicated for 5 minutes and aliquots of the prepared ink were cast on the surface for a total ceramic loading of $127 \mu \mathrm{g} \mathrm{cm}^{-2}$. The deposited droplet was then dried in air. After the ink was dried, $5 \mu 1$ of Nafion solution in ethanol (prepared by adding $9 \mathrm{ml}$ of ethanol to $1 \mathrm{ml}$ of a commercial 5\% Nafion solution, Sigma-Aldrich) were deposited on the disk on top of the mixed ceramic-graphite layer.

Cyclic voltammetry.-The electrochemical characterization was conducted in a three-electrodes electrochemical cell. The electrolyte consisted of $100 \mathrm{ml}$ of $0.5 \mathrm{M} \mathrm{H}_{2} \mathrm{SO}_{4}$ prepared by diluting concentrated sulfuric acid (95\%, Alfa Aesar) with de-ionized water. The reference electrode was an $\mathrm{Hg} / \mathrm{HgSO}_{4}$ electrode (Radiometer Analytical). The measured potential is referred to the Standard Hydrogen Electrode scale (SHE) by adding $658 \mathrm{mV}$ to the potential measured against $\mathrm{Hg} / \mathrm{HgSO}_{4}$. A Pt plate with a surface area of approximately $3 \mathrm{~cm}^{2}$ was used as a counter electrode. The solution was de-gassed with Ar for half an hour prior to each experiment. The working electrode was inserted into the solution at the open circuit potential (OCP) and the cyclic voltammograms were recorded with a $\mathrm{CH} 760 \mathrm{E}$ bipotentiostat ( $\mathrm{CH}$ instruments) with a scan rate of $5 \mathrm{mV} \mathrm{sec}{ }^{-1}$. The rotation speed was set at $1600 \mathrm{rpm}$, a rotation speed often used for the electrochemical characterization of catalyst and materials in the conditions analyzed in this study (for example, see Refs. 42-46).

Scanning electron microscopy (SEM).- To prepare the samples for the SEM analysis, one side of an adhesive carbon tape disk was put in contact with the deposited material on the disk of the RRDE and made to adhere adequately by applying pressure. An SEM holder was placed in contact with the other side of the adhesive disk. When the SEM holder was lifted from the surface of the RRDE, the carbon tape disk remained attached to it, taking away from the surface of the RRDE disk a good portion of the cast composite. The images were collected using a Zeiss Merlin Field Emission Gun Scanning Electron Microscope.

$X$-ray photoelectron spectroscopy (XPS) and inductive coupled plasma-optical emission spectroscopy (ICP-OES)._XPS data presented in this work were performed on a K-alpha (Thermo Electron Limited), using a monochromatic Al-K X-ray source with a $400 \mu \mathrm{m}$ spot size. All samples were mounted on the sample holder, which resulted in a chamber pressure of $5 \times 10^{-7} \mathrm{mbar}$. Atomic concentrations were determined from the average of three broad range spectra and were determined from integrating peak intensities of the characteristic peaks. The broad range spectra were acquired in the range $0-1$, $300 \mathrm{eV}$, and collected with $200 \mathrm{eV}$ detector pass energy, $50 \mathrm{~ms}$ dwell time, 1.0 energy step size, and collected over three scans. Peaks were fit using a full width at half maximum (FWHM) of $1.4 \mathrm{eV}$ and an $85 \%$ Lorentzian/Gaussian function. The binding energies were referenced to the $\mathrm{Au} 4 \mathrm{f}$ peak at $84.0 \mathrm{eV}$.

The ICP-OES measurements were aimed to quantify the dissolved species in the solutions were the materials were tested toward corrosion both chemically and electrochemically. The measurements were conducted using a Varian Vista Axial ICP-OES and the analysis was done using external standards of the elements of interest $(\mathrm{Cu}, \mathrm{Cr}, \mathrm{Mn}$ and $\mathrm{Ni}$ ).

\section{Results and Discussion}

Cyclic voltammetry.-The first cycles of the $\mathrm{CV}$ experiments are reported in Figure 2. At high potentials (close to $2.0 \mathrm{~V}$ vs SHE) the anodic current is similar in both the ceramic samples and GC

a)
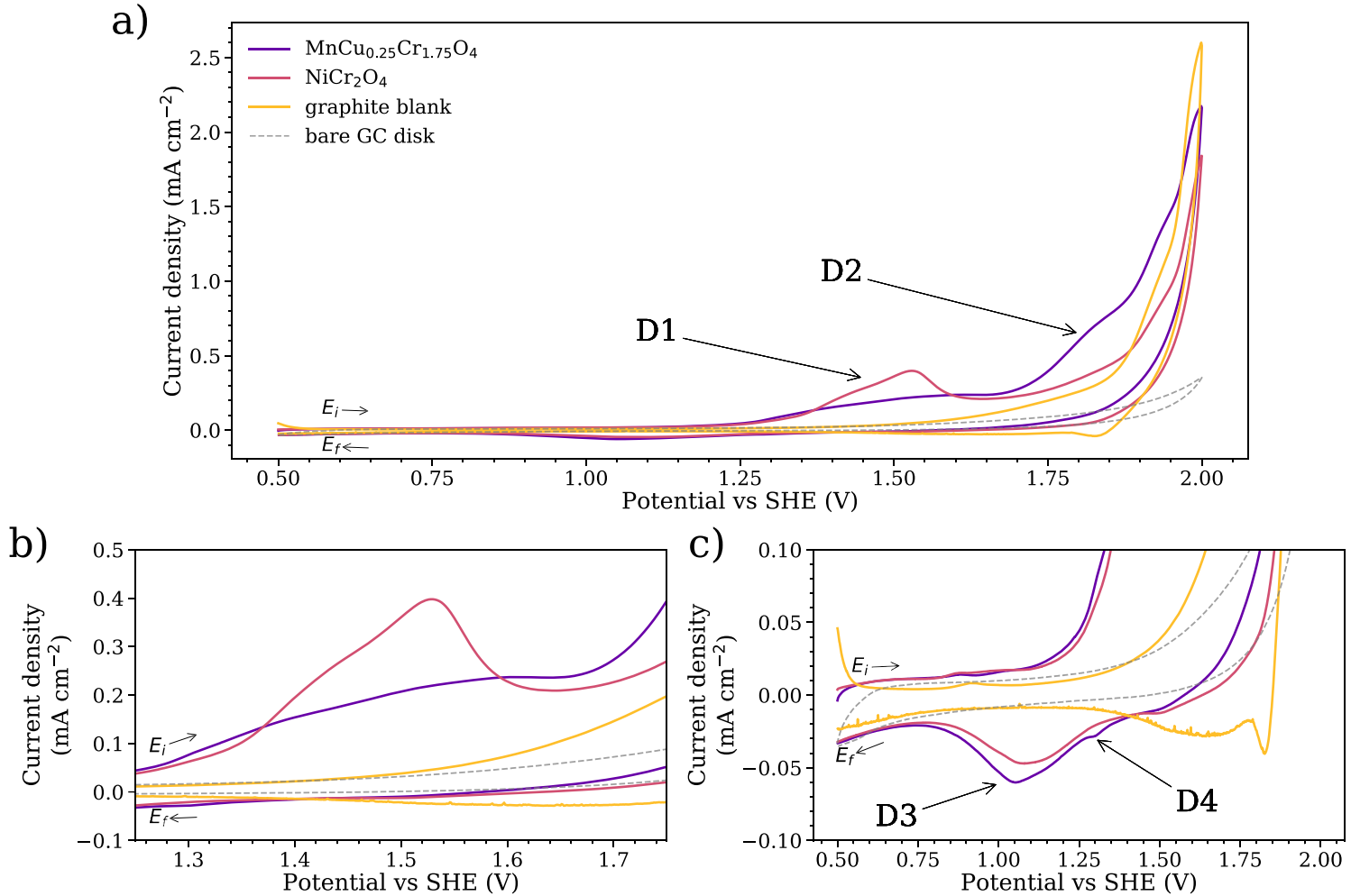

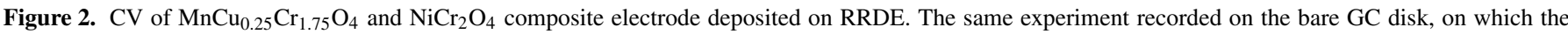

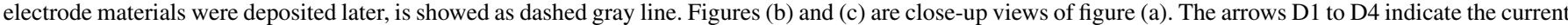

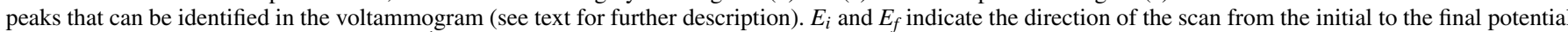
respectively [0.5-2.0 V vs SHE, $5 \mathrm{mV} \mathrm{sec}{ }^{-1}$, RE: $\mathrm{Hg} / \mathrm{HgSO}_{4}$, Ar-saturated $0.5 \mathrm{M} \mathrm{H}_{2} \mathrm{SO}_{4}, 1600 \mathrm{rpm}$ ]. 
electrode. In this region, the current is dominated by carbon oxidation to either $\mathrm{CO}_{2}$ or $\mathrm{O}$-containing functional groups on the surface of the glassy carbon. A comparison with the blank experiment can nevertheless highlight the presence of distinctive anodic and cathodic features for both the ceramic materials. Specifically, in the anodic sweep of the $\mathrm{CVs}$, a peak is distinguishable around $1.6 \mathrm{~V}$ (D1, D for disk). In the case of $\mathrm{NiCr}_{2} \mathrm{O}_{4}$, the peak is well resolved, while it appears broader in the case of $\mathrm{MnCu}_{0.25} \mathrm{Cr}_{1.75} \mathrm{O}_{4}$. A second feature is present in anodic branch of the $\mathrm{CV}$ from $\mathrm{MnCu}_{0.25} \mathrm{Cr}_{1.75} \mathrm{O}_{4}$ around $1.85 \mathrm{~V}$ (D2), which is not present in the case of $\mathrm{NiCr}_{2} \mathrm{O}_{4}$. The cathodic sweep of the CVs again shows distinctive features. A clear cathodic peak centered at $1.0 \mathrm{~V}$ (D3) is present in both $\mathrm{MnCu}_{0.25} \mathrm{Cr}_{1.75} \mathrm{O}_{4}$ and $\mathrm{NiCr}_{2} \mathrm{O}_{4}$, while a flat capacitive contribution is present around that potential in the case of the blank experiment. A smaller but evident peak can be seen in the $\mathrm{CV}$ of $\mathrm{MnCu}_{0.25} \mathrm{Cr}_{1.75} \mathrm{O}_{4}$ around 1.3 V (D4). In the case of the blank experiment, a sharp peak can be noticed right after the scanning direction inversion, followed by a broader signal which disappears before $1.2 \mathrm{~V}$. It is known that oxidation of graphite can lead to the formation electrochemically active functional groups on the surface of the material, but the electrochemistry of such species happens at lower potentials. ${ }^{47}$ As mentioned above, graphite is known to be able to form intercalation compounds with $\mathrm{SO}_{4}{ }^{2-}$ ions when polarized at sufficiently high potentials, and those signals can be due to de-intercalation processes taking place on the surface of the graphite. In fact, the shape of the $\mathrm{CV}$ in that region closely resembles the one reported by Besenhard et $\mathrm{al}^{48}$ for oxidation-reduction of crystalline porous graphite in the presence of $\mathrm{LiClO}_{4}$ (where the ion $\mathrm{ClO}_{4}{ }^{-}$is expected to intercalate at high potentials). The reason why those peaks are not present when the graphite is mixed with the ceramic material can be that kinetically more accessible processes involving the ceramic material (oxidation/ dissolution, OER) are taking place preferentially. Those graphiterelated features were not further investigated: since they were present at sufficiently different potentials compared with ceramic-related signals, their influence on the following data analysis was considered not important for semi-quantitative analysis of the oxidation of the ceramics.

While the disk was scanned, the Pt ring was held at $0.5 \mathrm{~V}$. The ring was able to collect species coming from the dissolution processes taking place at the disk. In Figure 3a, the disk and ring current recorded from the first $\mathrm{CV}$ cycle are displayed as a function of time. The ring current has been corrected for the collection efficiency stated by the supplier of the RRDE (see Experimental section) and multiplied by a factor of 10 for a better graphical clarity. In the case of the blank experiment, no distinguishable signals from the baseline can be observed, with the exception of a small increase in cathodic current at the time the disk reaches $2.0 \mathrm{~V}$, which can be attributed to OER taking place on graphite/GC. In the case of the ceramic materials, the ring current increases sharply when the characteristic anodic signals on the disk are appearing. For both the materials, a cathodic current develops on the ring after the ring passes $1.25 \mathrm{~V}$ (peak $\mathrm{R} 1, \mathrm{R}$ for ring), with the

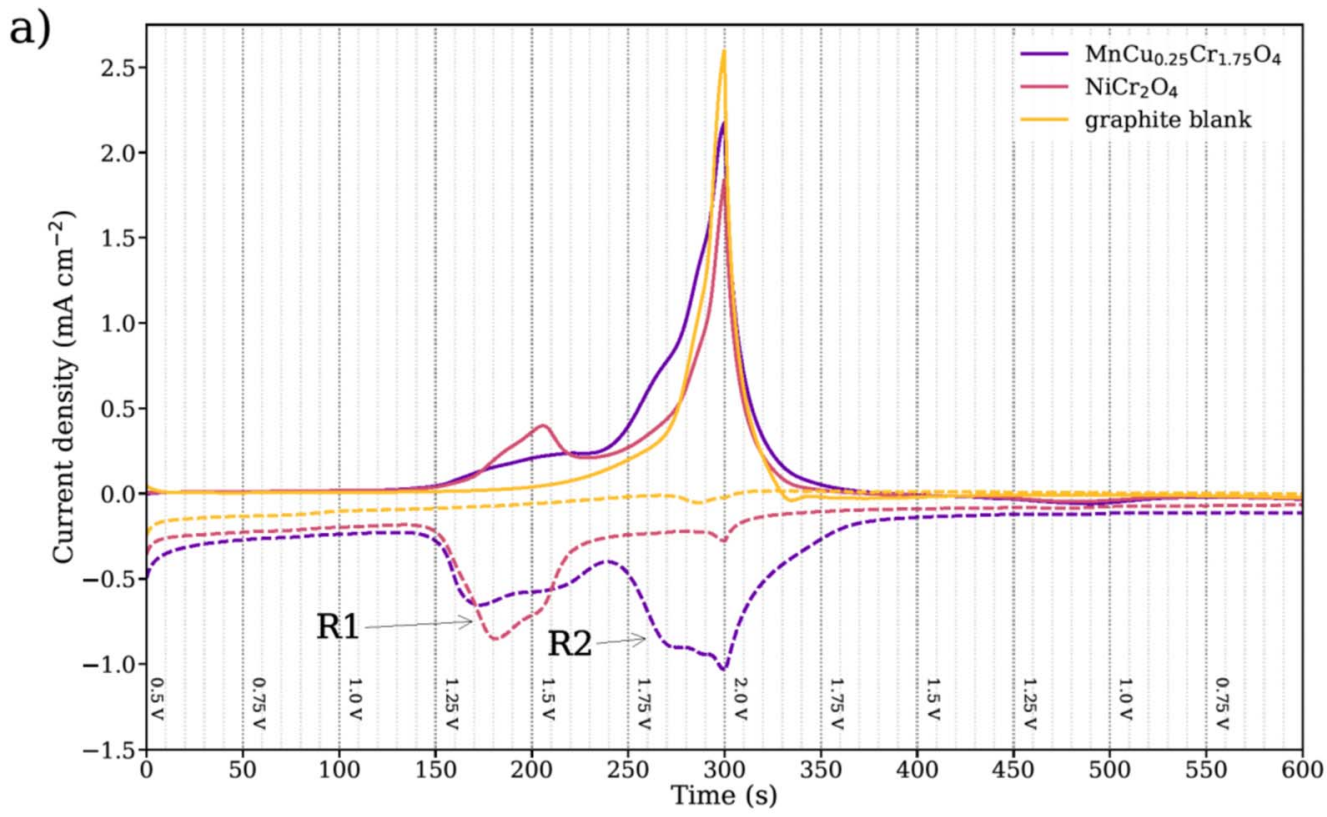

b)

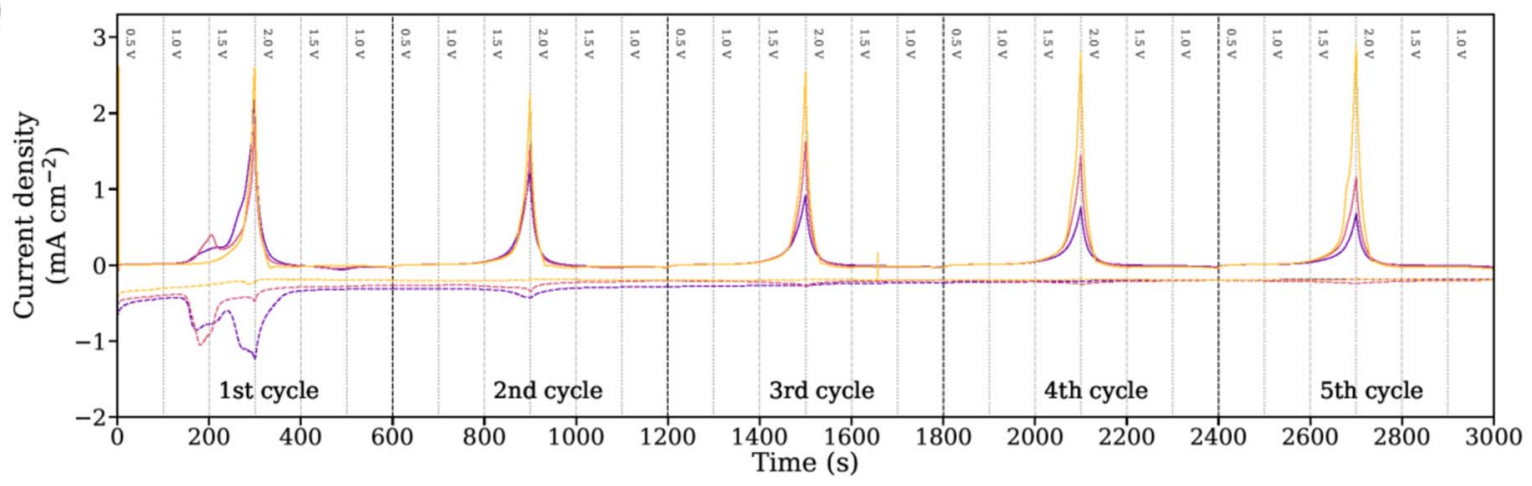

Figure 3. $\mathrm{CV}$ of $\mathrm{MnCu}_{0.25} \mathrm{Cr}_{1.75} \mathrm{O}_{4}$ and $\mathrm{NiCr}_{2} \mathrm{O}_{4}$ composite electrode deposited on RRDE plotted as a function of time showing both the disk current (solid line) and the ring current (dashed line). The ring current has been multiplied by a factor of 10 for a better graphical clarity. The vertical lines indicate the potential vs SHE applied at the disk at each time; (a) first cycle; (b) first five cycles [0.5-2.0 V vs SHE, $5 \mathrm{mV} \mathrm{sec}^{-1}, \mathrm{RE}: \mathrm{Hg} / \mathrm{HgSO}_{4}, \mathrm{Ar}_{-} \mathrm{saturated}_{0.5 \mathrm{M} \mathrm{H}} \mathrm{SO}_{4}, 1600 \mathrm{rpm}$ ]. 


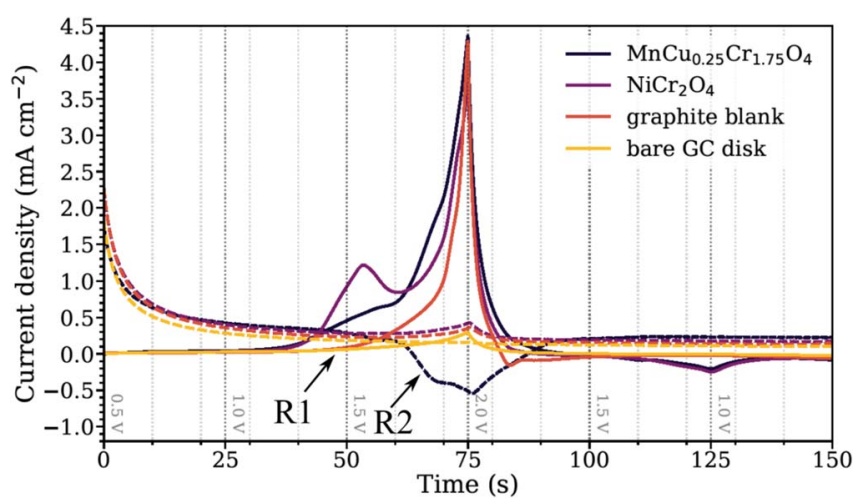

Figure 4. $\mathrm{CV}$ of $\mathrm{MnCu}_{0.25} \mathrm{Cr}_{1.75} \mathrm{O}_{4}$ and $\mathrm{NiCr}_{2} \mathrm{O}_{4} \mathrm{CV}$ composite electrode deposited on RRDE plotted as a function of time showing both the disk current (solid line) and the ring current (dashed line). The ring current has been multiplied by a factor of 10 for a better graphical clarity, after being corrected for the collection efficiency. The vertical lines indicate the potential vs SHE applied at the disk at each time. [DISK: 0.5-2.0 V vs SHE, $20 \mathrm{mV} \mathrm{sec}^{-1}$; RING: $1.2 \mathrm{~V}$ vs $\mathrm{SHE}$; $\mathrm{RE}$ : $\mathrm{Hg} / \mathrm{HgSO}_{4}$, Ar-saturated $\left.0.5 \mathrm{M} \mathrm{H}_{2} \mathrm{SO}_{4}, 1600 \mathrm{rpm}\right]$.

signal apparently mirroring the developing of the anodic peak on the disk.

Nature of dissolution products.-Both the materials show a similar current signal on the ring despite the different compositions, suggesting that the cathodic signal (and therefore the anodic signal on the disk) is related to $\mathrm{Cr}$ redox activity. As mentioned before, $\mathrm{Cr}$ dissolves as $\mathrm{CrO}_{4}{ }^{2-}$ upon anodic polarization and it is protonated to $\mathrm{HCrO}_{4}{ }^{-}$in a solution of $0.5 \mathrm{M}$ sulfuric acid. Even if no oxidation was involved in the dissolution, the reduction of $\mathrm{Cr}$ (III)in acid solution cannot take place at potentials $>0 \mathrm{~V}$ vs SHE, whatever the reduction product. ${ }^{28}$ Therefore, the cathodic peak R1 is probably due to reduction of $\mathrm{Cr}$ species according to Equations 1 or 3 . The reduction must involve $\mathrm{Cr}$ species with higher valency, the most stable aqueous species being $\mathrm{Cr}(\mathrm{VI})$. Interestingly, R1 peaks before D1 for both the materials. In Figure $3 b$, the evolution of the current upon cycling can be observed. After the first cycle, the signal from the disk where the ceramic materials are deposited resembles the current behavior of the blank experiment, suggesting that no further evident faradaic process takes place at the disk. The ring current, after the first cycle, shows an increase in cathodic current when the disk approaches $2.0 \mathrm{~V}$, similar to the one observed for the blank experiment, but with higher absolute current density (especially in the case of $\mathrm{MnCu}_{0.25} \mathrm{Cr}_{1.75} \mathrm{O}_{4}$ ). The second cathodic peak in the ring current (R2) in the case of $\mathrm{MnCu}_{0.25} \mathrm{Cr}_{1.75} \mathrm{O}_{4}$ is more difficult to identify. It can be attributed to the material, after comparison with the blank experiment. Nevertheless, multiple reactions beside the oxidative dissolution of the ceramic can take place: above all, OER, together with the parasitic reaction connected to it, such as $\mathrm{H}_{2} \mathrm{O}_{2}$ production. Manganese oxides $\left(\mathrm{MnO}_{\mathrm{x}}\right)$ are known to possess a certain activity toward oxygen evolution ${ }^{49,50}$ and it can be expected from the Mn-containing compound to exhibit activity toward oxygen evolution. In order to identify the nature of the species associated with peak R2, the same experiment was conducted holding the ring at $1.2 \mathrm{~V}$ vs SHE, where $\mathrm{O}_{2}$ cannot be reduced on $\mathrm{Pt}$ and $\mathrm{H}_{2} \mathrm{O}_{2}$ (often present as a side product of OER) is oxidized to $\mathrm{O}_{2}$. Figure 4 displays the obtained voltammograms.

The initial current decay common to all the samples observed for the ring current is the current transient coming from the growth of $\mathrm{Pt}$ oxides on the surface of the ring. No cathodic signal is observed in the case of $\mathrm{NiCr}_{2} \mathrm{O}_{4}$, graphite blank and GC. In fact, the potential is too high for the reduction/oxidation of $\mathrm{O}_{2} / \mathrm{H}_{2} \mathrm{O}_{2}$. The potential is also probably too high for the reduction of $\mathrm{HCrO}_{4}{ }^{-}$(for which the standard potential of reduction to $\mathrm{Cr}^{3+}$ is 1.38 or $1.36 \mathrm{~V}$ vs $\mathrm{SHE}$, for reduction of $\mathrm{HCrO}_{4}{ }^{-}$or $\mathrm{Cr}_{2} \mathrm{O}_{7}{ }^{2-}$ respectively, see Eqs. 1 and 3) as no peak is observed in the position of $\mathrm{R} 1$. In the case of $\mathrm{MnCu}_{0.25} \mathrm{Cr}_{1.75} \mathrm{O}_{4}$, a cathodic current appears on the ring after the disk passes $1.7 \mathrm{~V}$, indicating that a reduction is taking place at the ring. The standard potential of reduction of $\mathrm{MnO}_{4}{ }^{-}$is $1.77 \mathrm{~V}$ vs SHE (see Eq. 4) which means that an overpotential of more than $500 \mathrm{mV}$ is present at the Pt ring toward the reduction of permanganate. It can then be deduced that the cathodic peak on the ring is at least partly due to the reduction of permanganate to $\mathrm{MnO}_{\mathrm{x}}$. $\mathrm{R} 2$ shows a clear difference in its total area (charge) when it is held at 0.5 or $1.2 \mathrm{~V}$ vs SHE, as can be seen comparing Figures 3 and 4. This fact may indicate that, on the disk at potentials between 1.7 and $2.0 \mathrm{~V}$, several concurrent reactions are taking place, such as $\mathrm{OER}, \mathrm{H}_{2} \mathrm{O}_{2}$ production, and $\mathrm{Mn}$ oxidation. The product of some of those reactions can be reduced on the ring when it is held at $0.5 \mathrm{~V}$ vs SHE but not when it is at $1.2 \mathrm{~V}$ vs SHE. The difference in area could also be explained by only one reaction (e.g. $\mathrm{MnO}_{4}{ }^{-}$reduction), driven to different degrees of completion by the ring being held at 0.5 or $1.2 \mathrm{~V}$ vs SHE. It is reported that higher OER activity of $\mathrm{MnO}_{\mathrm{x}}$ is related to the presence of $\mathrm{Mn}(\mathrm{III})$, which is present on $\mathrm{MnCu}_{0.25} \mathrm{Cr}_{1.75} \mathrm{O}_{4}$ due to oxidation of the native $\mathrm{Mn}$ (II) constituent ions and the product of the partial inversion due to exchange with $\mathrm{Cu}^{2+}$ in octahedral position, as shown elsewhere. ${ }^{38}$ It can be assumed that the main cause for the peak in cathodic current observed on the ring held at $0.5 \mathrm{~V}$, when the disk is at $2.0 \mathrm{~V}$, is due to $\mathrm{O}_{2}$ reduction. A decrease of absolute cathodic current on the ring upon cycling can be interpreted as the progressive oxidation of Mn ions present on the surface of the material to stable but OER-inactive Mn(IV) ions, which then lead to a decrease in the oxygen evolution current.

Origin of the cathodic peaks.-As can be seen in Figure 2, the CV shows the presence of distinctive cathodic peaks, labeled D3 and D4. The cathodic peak D3 has been observed previously for the reduction of $\mathrm{HCrO}_{4}{ }^{-}$ion. ${ }^{26}$ The presence of the peak D4 only in the case of $\mathrm{MnCu}_{0.25} \mathrm{Cr}_{1.75} \mathrm{O}_{4}$ suggests that the peak may be related to the presence of $\mathrm{Mn}(\mathrm{Cu}$ redox activity is found at much lower potentials, as explained before). In fact, a similar sharp peak is reported by Godunov et al. ${ }^{29}$ for the reduction of $\mathrm{MnO}_{2(\mathrm{~s})}$ to $\mathrm{Mn}(\mathrm{II})_{(\mathrm{aq})}$. The presence of cathodic peaks D3 and D4 during the negative going sweep (NGS) may indicate a certain degree of reversibility of the reaction taking place on the disk during the positive going sweep (PGS), and be related to the reduction of $\mathrm{Cr}(\mathrm{VI})$ and $\mathrm{Mn}(\mathrm{IV})$ species on the surface of the ceramic material. Indeed, the presence of cathodic peaks in the first cycle (and the following cycles) is not correlated to the presence of an anodic peak in the subsequent PGS. As can be observed in Figure 3b, the cathodic peaks fade later than the anodic peaks. To further investigate such phenomenon, the experiments were repeated by increasing the upper potential of the $\mathrm{CV}\left(E_{u}\right)$ progressively at each cycle up to $2.0 \mathrm{~V}$ vs SHE.

Figure 5 shows the results of such experiments for $\mathrm{NiCr}_{2} \mathrm{O}_{4}$. The same experiments have been conducted for $\mathrm{MnCu}_{0.25} \mathrm{Cr}_{1.75} \mathrm{O}_{4}$ (not displayed here) and the following discussion can be considered valid for this material also. In order to get a current signal which was sensibly differing from the background current, the ceramic loading was doubled (total loading: $255 \mu \mathrm{g} \mathrm{cm}^{-2}$ ). The maximum potential reached, $E_{u}$, was increased at each cycle of $0.05 \mathrm{~V}$ starting from 1.15 to $1.95 \mathrm{~V}$. In the following text, the experiment is referred to as a variable $E_{u}$ experiment. A CV experiment where the potential was continuously scanned with the same scan rate from 0.5 to $2 \mathrm{~V}$ is also shown in the figure, identified in the following text as continuous experiment. The single cycles with variable $E_{u}$ presents higher total current densities in the positions where the current peaks and waves are present in the continuous $\mathrm{CV}$, both in the case of disk and ring current densities. The results also further highlight the potential dependence of the processes taking place on the disk. Beside lower absolute values of the current density in the case of the variable $E_{u}$ experiment, a clear difference with the continuous scan experiment is the absence of the cathodic peaks D3 and D4. In the case of the continuous $\mathrm{CV}$, the fact that the presence of D3 and D4 is not correlated to any restoration of anodic activity during the subsequent PGS suggests that the reactions causing the peaks are not simply the reverse process of the ones originating the anodic peaks in the previous PGS. Moreover, the cathodic peaks fade away upon cycling (see Fig. 5b) without any comparable change in 
a)

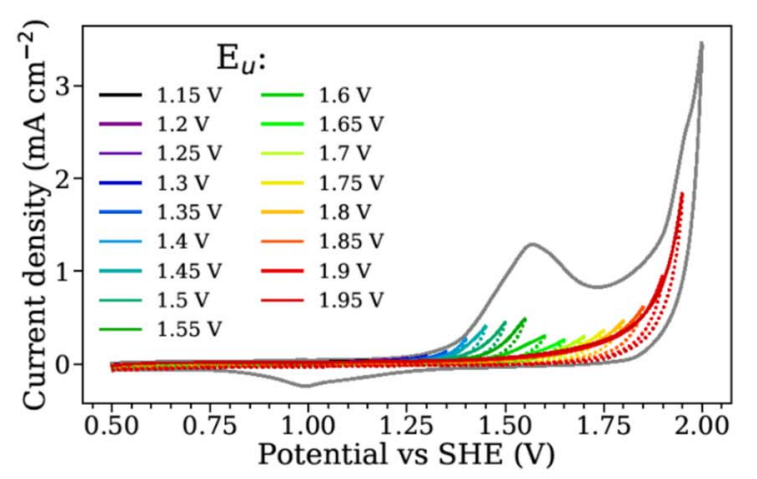

C)

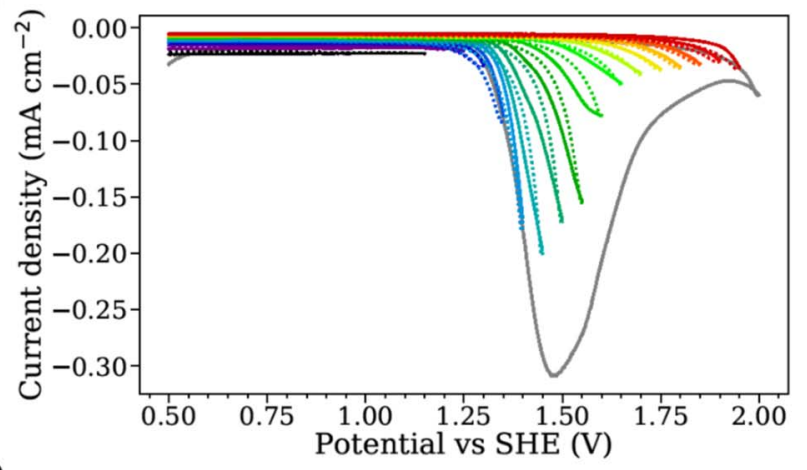

b)

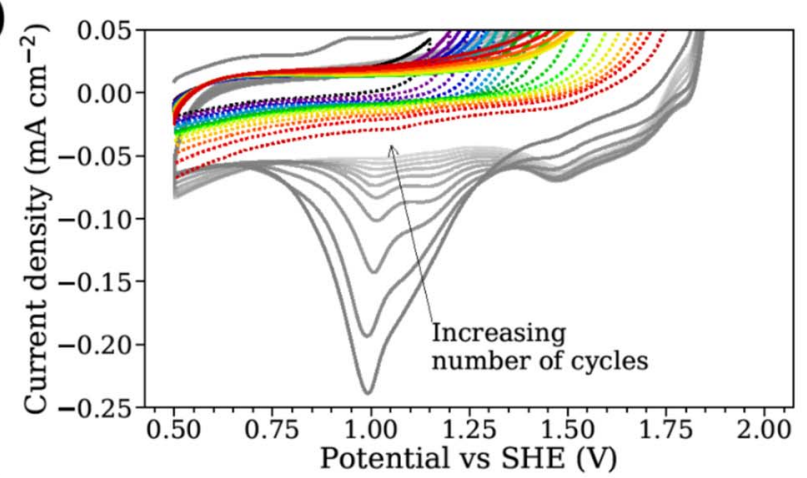

d)

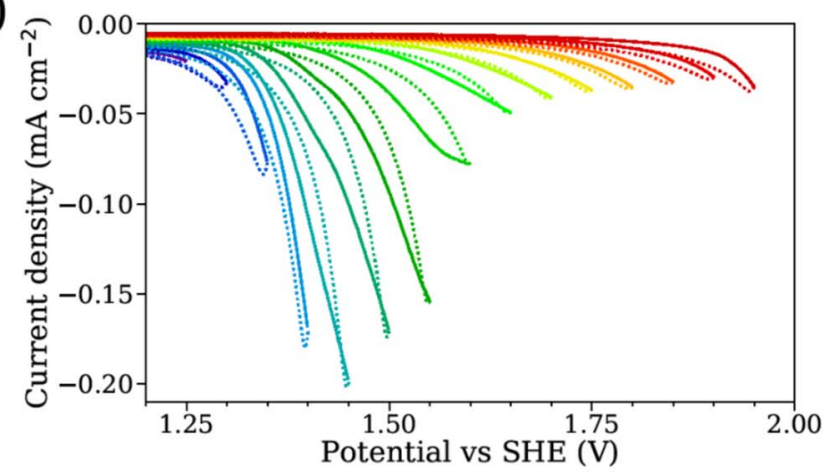

e)

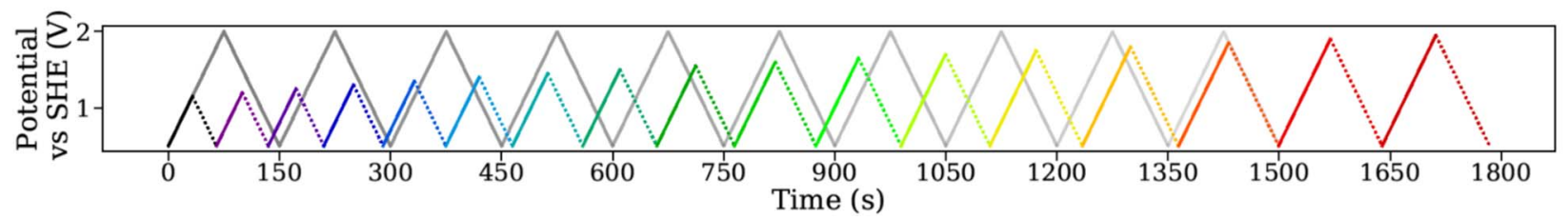

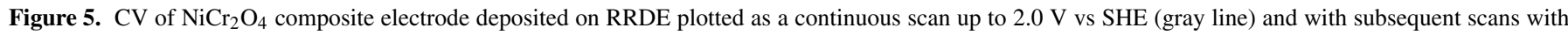

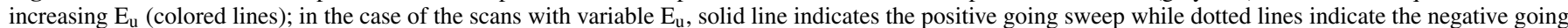

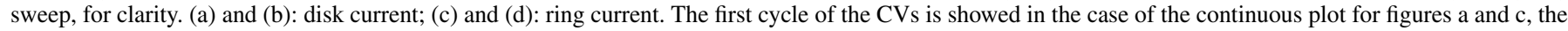

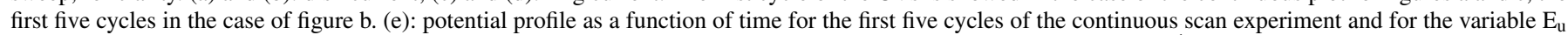

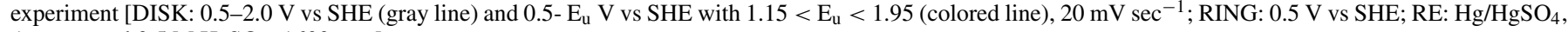
Ar-saturated $\left.0.5 \mathrm{M} \mathrm{H}_{2} \mathrm{SO}_{4}, 1600 \mathrm{rpm}\right]$.

the anodic side of the CV. In fact, the anodic current is present on the disk almost exclusively in the first cycle. Given these observations, it can be inferred that the cathodic peaks observed on the disk are due to the reduction of soluble products of the oxidation of the ceramic, which could not escape the composite cast layer during the time frame of one single cycle. During the experiments, the electrolyte is continuously dragged toward the electrode by the rotation of the RDE. A soluble species produced on the disk which remains loosely adsorbed on the electrode would eventually be transported away by the flux due to the constant rotation. If the potential on the disk becomes negative enough while the reactive adsorbed species are present in a high enough concentration, then the adsorbed species can be reduced on the disk prior to be dragged away by the flux of electrolyte, thus causing an observable cathodic signal. The emergence of a cathodic signal would therefore be time dependent on the experiment time scale, i.e. the cathodic peak will be present as far as the flux of electrolyte does not remove all the adsorbed species from the disk electrode.

Figure 5e shows the potential applied on the disk as a function of time for the continuous scan experiment ( 10 cycles) and for the variable $E_{u}$ experiment. The soluble species are generated by the oxidation reactions. As the anodic processes take place mainly during the first anodic scan (75 s) in the continuous experiment, the soluble species are generated predominantly in such a period of time. Parts of the soluble products leave the electrode and are collected at the ring, and parts of them stay adsorbed on the disk and are reduced when the potential on the disk becomes less than $1.1 \mathrm{~V}$ vs SHE, originating the cathodic peaks. In fact, if the soluble product is $\mathrm{HCrO}_{4}{ }^{-}$, then the potential is below the standard potential of the reaction reported in Equation 2. On the other hand, the cathodic peaks can observed up to the $10^{\text {th }}$ cycle, even if no anodic peak is present at the same time. At this point, the adsorbed species are either reduced or have been removed from the disk by the continuous stream of electrolyte. 10 cycles (1500 s) are then necessary to remove the products of the anodic processes in the first PSG (75 s). In the experiment with increasing $E_{u}$, each cycle produces a fraction of the total amount of soluble species produced in the first continuous cycle, since $E_{u}<2 \mathrm{~V}$ always. As can be observed in Figure 5a, the oxidation process (which generates the soluble species) can be considered complete when the potential is $>1.75 \mathrm{~V}$ vs SHE. In the case of the increasing $E_{u}$ experiment, such potential is reached only after the $13^{\text {th }}$ cycle, corresponding to $1324 \mathrm{~s}$. This means that the same amount of soluble species produced in $75 \mathrm{~s}$ in the case of the continuous scan experiment are produced in $1324 \mathrm{~s}$ in the case of the increasing $E_{u}$ experiment. In such larger time scale, the soluble species adsorbed on the disk are, at each cycle, probably too low in concentration or carried away fast enough by the electrolyte flux not to allow the recording of an observable reduction current. Therefore, the cathodic peaks D3 and D4 are not observed in such experiment. Given the above discussed results, Figure 6 summarizes the proposed interpretation of the phenomena observed during the $\mathrm{CV}$ experiments for the electrochemical anodic dissolution of $\mathrm{Cr}$ oxides.

The materials under study underwent oxidation/dissolution processes at potentials as low as $1.25 \mathrm{~V}$ vs SHE. Such a potential is 


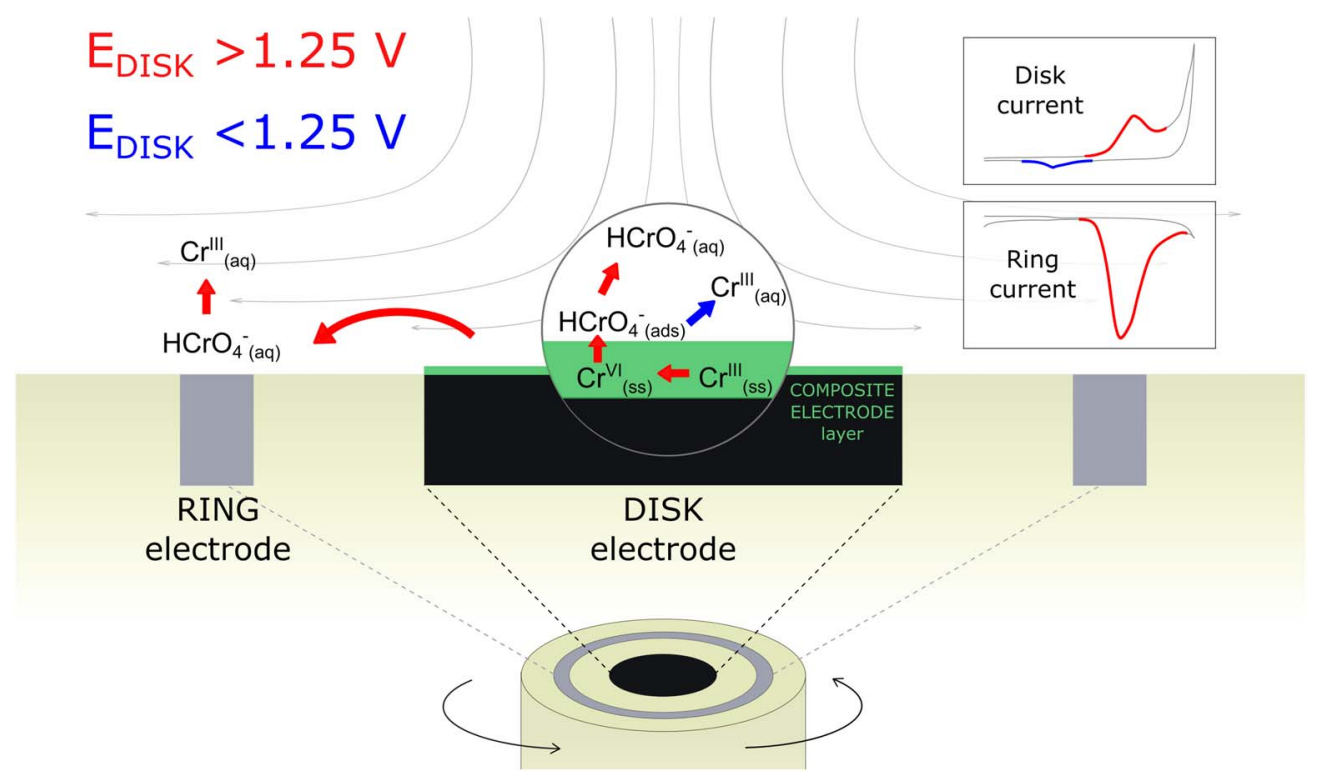

Figure 6. Scheme of the interpretation of the processes observed by CV on the ceramics relative to the oxidation of Cr species in the ceramics. The scheme represent a cross section of a RRDE. Red arrows indicate the processes taking place when the potential of the disk is greater than $1.25 \mathrm{~V}$ vs SHE, blue arrows indicate the processes taking place when the potential is lower than $1.25 \mathrm{~V}$ vs SHE. On the right, the current resulting from those processes is indicated in the CVs with the same color code. The subscripts 'ads', 'aq' and 'ss' indicate species adsorbed in the composite electrode layer, aqueous species and species in solid phase respectively. RING: $0.5 \mathrm{~V}$ vs SHE. See text for further description.

expected to be experienced by a material in the anode compartment of a PEMEC. In fact, OER in acidic environment is reported to take place starting at potentials between 1.4 and $1.5 \mathrm{~V}$ vs SHE. ${ }^{43,45,51}$ Therefore, chromites spinels appear to be not stable in the conditions required for the application.

Oxidation charge and semi-quantitative analysis.-The integration of the $\mathrm{CV}$ areas can give information on the amount of reactive material relative to the total amount deposited on the electrode that undergoes electrochemical reactions. The evaluation of the baseline for integration is not trivial when multiple peaks are overlapping. As a first approach (approach A), the signal coming from the blank graphite experiment can be subtracted, which includes the contribution of graphite itself and of GC electrode. Moreover, in the region under analysis OER can be expected to become a significant contribution, after the potential passes $1.23 \mathrm{~V}$. Integration of the ceramic related peaks even after the subtraction of the blank signal will include also the charge coming from OER faradaic processes, if the ceramic composite electrode and the blank composite electrode have different activity toward OER. Thus, this integration approach is expected to be an overestimation of the charge assigned to the ceramic redox processes. Another integration approach (approach B) can be direct extrapolation of the peak area by using a straight line at the base of the peak as a baseline. This approach removes possible inclusion of OER currents: oxygen evolution involves water as a reactant and therefore, in an aqueous environment a Tafel behavior can be expected, limited only by electrolyte resistance, and no peak arising from diffusion control of the reaction can be expected; any resolved peak can be ascribed to characteristic faradaic processes involving the ceramic materials. Nevertheless, this approach can lead to underestimation of the charge involved, since the baseline has not strictly speaking any physical meaning and it is ultimately drawn arbitrarily. For the purpose of the integration and given the analysis described above, the integration of peaks $\mathrm{R} 1$ and $\mathrm{D} 1$ have been attributed to $\mathrm{Cr}$ and conducted considering a three electrons process according to Equations 1 or 3, while peaks R2 and D2 have been attributed to Mn and integrated considering a three electrons process according to Equation 4. Only the very first cycle showed a clear peak. The integration with the different approaches, even if not quantitative, can give information on the portion of material that undergoes faradaic reactions. The approaches can be regarded as boundary limits for under-/over-estimation, meaning that the real value must lay in between the values obtained with the two approaches.

Figure 7 illustrates the two approaches for $\mathrm{NiCr}_{2} \mathrm{O}_{4}$ and $\mathrm{MnCu}_{0.25} \mathrm{Cr}_{1.75} \mathrm{O}_{4}$, together with the resulting integrated charges as a function of the number of cycles (Fig. 7c). The integrated charges evolution upon cycling show that only a fraction of the total amount of moles undergoes oxidation during the $\mathrm{CV}$ experiment. The evolution of the cumulative integrated charge appears to reach a plateau after a few cycles. The integrated charges corresponding to ring currents are corrected considering the collection efficiency of the RRDE, but the absolute values of the integrated areas are well below the values obtained by integration of the disk current, suggesting that not all the oxidation products leave the disk after oxidation. Even assuming that the cathodic peaks D3 and D4 are caused by trapped soluble oxidation products, adding the integration results of those peaks to the ring current to quantify the dissolved materials (not reported) does not influence significantly the amounts of integrated charges. Therefore, the oxidation of the material takes place predominantly in the first anodic sweep of the voltammetry without complete oxidation of the material under study. To observe the effect of potential cycling on the composite cast electrode, SEM images were collected on the cast material before and after the $\mathrm{CV}$ experiment.

The images are shown in Figure 8. In the low magnification images (Figs. 8a, 8b, 8c and 8d) the general morphology of the cast composite can be observed. There is a clear difference in average particle size between and graphite and ceramic particles. Moreover, it can be observed that the ceramic is still present in the composite and that it did not undergo complete dissolution upon cycling. No striking difference in morphology of the cast electrode can be observed before and after the CV experiment. Higher magnification images (Figs. 8e, 8f, 8g and $8 \mathrm{~h}$ ) further show that no major change in the general aspect of the particles has occurred after the cycling. In the case of $\mathrm{MnCu}_{0.25} \mathrm{Cr}_{1.75} \mathrm{O}_{4}$ it can be observed that some particles experienced a roughening of the surface together with the emergence of a layered appearance on the surface (Fig. 8f: dashed lines enclose areas where roughening can be observed, arrows indicate points where a layered morphology is more evident). This change in morphology can be due to etching of the surface. 

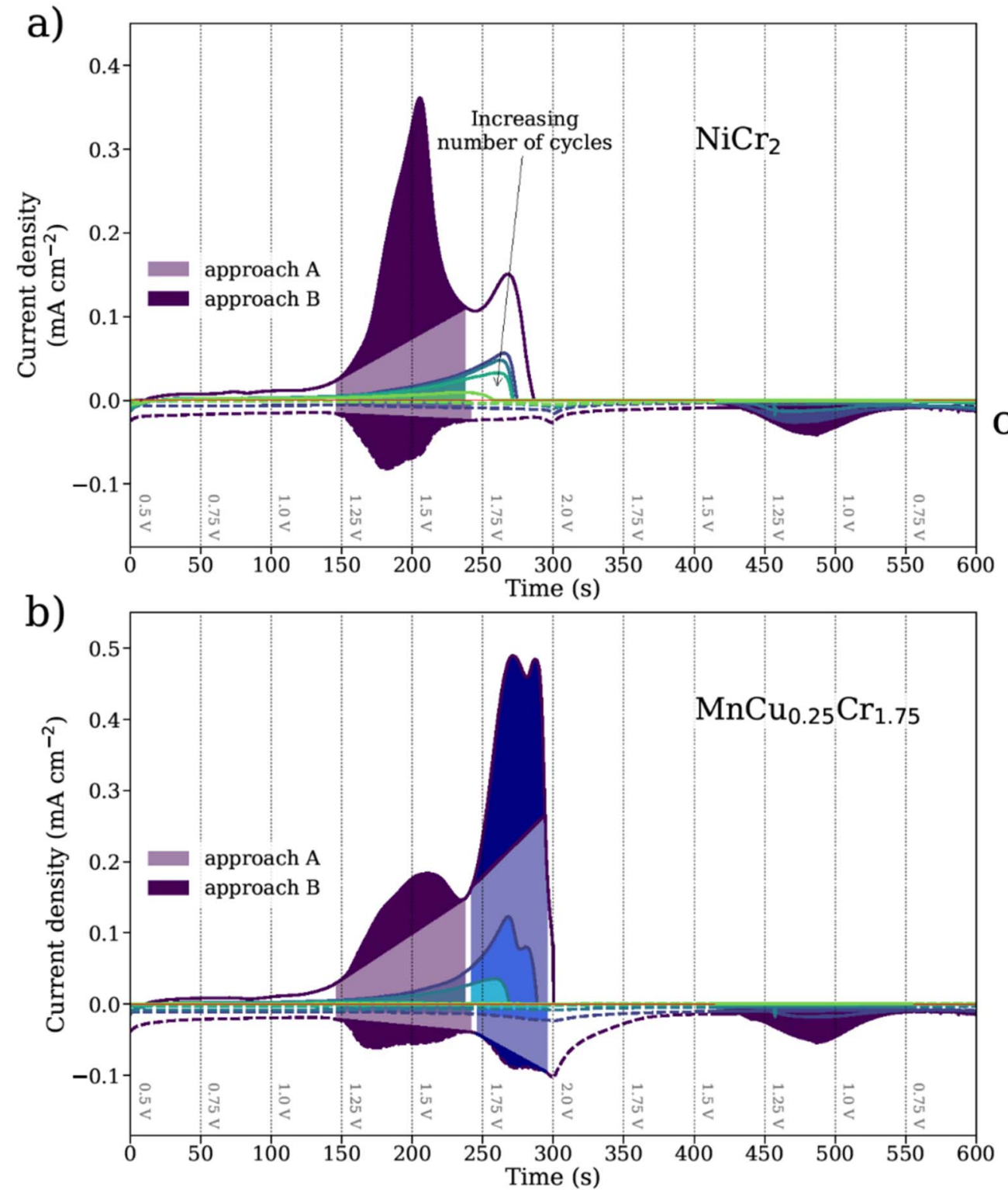

C)

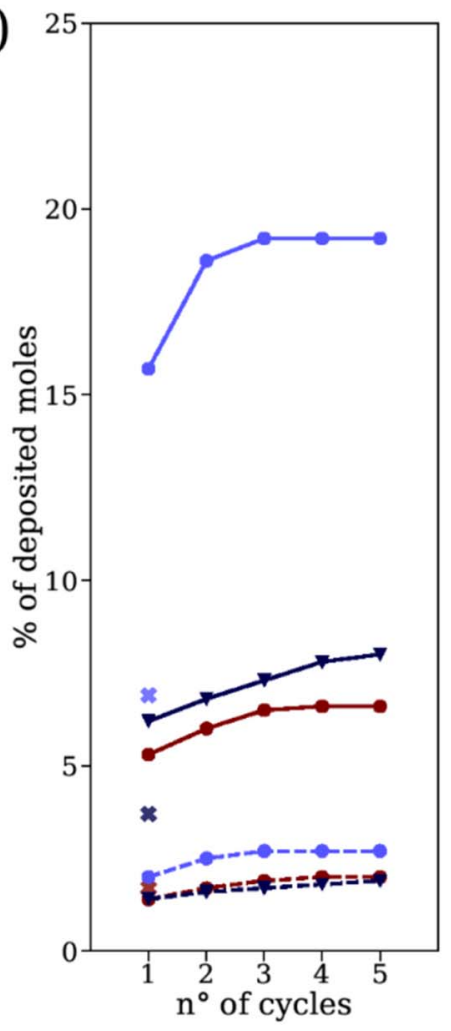

Figure 7. $\mathrm{CV}$ of $\mathrm{MnCu}_{0.25} \mathrm{Cr}_{1.75} \mathrm{O}_{4}$ and $\mathrm{NiCr}_{2} \mathrm{O}_{4}$ composite electrode deposited on RRDE plotted as a function of time showing both the disk current (solid line) and the ring current (dashed line). The ring current has been multiplied by a factor of 10 for a better graphical clarity. The vertical lines indicate the potential applied at the disk at each time. Figure (a) and (b) show the integrated area of the CV at different cycles with two different approaches for determining the baseline (see text); figure (c) shows the cumulative integrated charge as a function of the number of cycle of the integration. Again, solid and dashed lines correspond to disk and ring current respectively [DISK: $0.5-2.0 \mathrm{~V}$ vs SHE, $5 \mathrm{mV} \mathrm{sec}-1$; RING: $0.5 \mathrm{~V}$ vs SHE; RE: $\mathrm{Hg} / \mathrm{HgSO}_{4}, \mathrm{Ar}_{-}$saturated $0.5 \mathrm{M} \mathrm{H}_{2} \mathrm{SO}_{4}, 1600 \mathrm{rpm}$ ].

Surface and dissolved species composition.-To further investigate the products of such dissolution, XPS surface analysis was conducted on the samples before and after the chemical corrosion test reported elsewhere ${ }^{38}$ and the $\mathrm{CV}$ experiments conducted in this study. The samples analyzed before and after the CV experiments were prepared analogously as the ones used to collect SEM pictures. The test solutions of the experiments $\left(1: 1\right.$ mixture of $1 \mathrm{M} \mathrm{H}_{2} \mathrm{SO}_{4}$ and $\mathrm{HNO}_{3}$ acid in the case of chemical corrosion testing and $0.5 \mathrm{M} \mathrm{H}_{2} \mathrm{SO}_{4}$ in the case of CV experiments) were also analyzed by ICP-OES to determine the ratio of the species in solution as a consequence of dissolution. Figure 9 shows the results of the XPS and ICP-OES analysis, which are reported as molar ratios of the components of the ceramic materials. We are aware that contact dissolution can take place readily as the electrode gets in contact with the solution, even in the case of noble metal oxides. ${ }^{52}$ OCP measurements before the CV experiments (not shown) were between 0.5 and $0.8 \mathrm{~V}$ vs SHE. At such potentials, no species present in the materials under study is expected to undergo either oxidation or reduction, thus the contribution of contact dissolution to the overall material dissolution was considered negligible. The XPS results on the pristine samples show a good agreement of the measured molar compositions with the nominal one, with the exception of the measured content of $\mathrm{Cu}$ in $\mathrm{MnCu}_{0.25} \mathrm{Cr}_{1.75} \mathrm{O}_{4}$, which is slightly lower than the nominal value. In the case of $\mathrm{NiCr}_{2} \mathrm{O}_{4}$, the XPS analysis powder sample after the chemical corrosion test shows an enrichment in $\mathrm{Cr}$ on the surface of the material. The ICP-OES conducted on the test solution indicates that the dissolution of the components is congruent both in the chemical corrosion test and in the electrochemical test, with the relative amounts of $\mathrm{Ni}$ and $\mathrm{Cr}$ being close to the nominal composition of the material before the tests. The sample $\mathrm{MnCu}_{0.25} \mathrm{Cr}_{1.75} \mathrm{O}_{4}$ behaved differently. After the chemical corrosion test, the XPS results show that the $\mathrm{Cr}$ is higher compared to the nominal value and the values measured for the pristine samples. Notably, the enrichment of $\mathrm{Cr}$ on the surface of the tested sample is mirrored by a higher value of $\mathrm{Mn}$ and $\mathrm{Cu}$ in the metal content measured by 


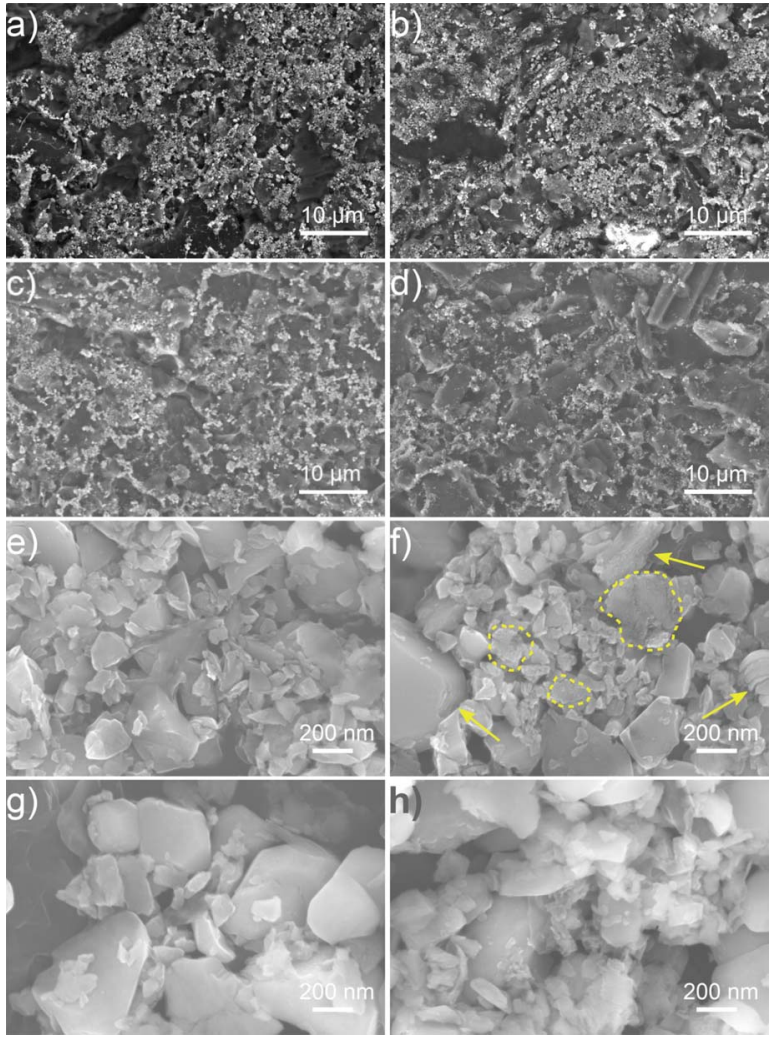

Figure 8. SEM images collected on samples of the RRDE-cast composites of $\mathrm{MnCu}_{0.25} \mathrm{Cr}_{175} \mathrm{O}_{4}(\mathrm{a}, \mathrm{b}, \mathrm{e}, \mathrm{f})$ and $\mathrm{NiCr}_{2} \mathrm{O}_{4}(\mathrm{c}, \mathrm{d}, \mathrm{g}, \mathrm{h})$ before $(\mathrm{a}, \mathrm{c}, \mathrm{e}, \mathrm{g})$ and after $(\mathrm{b}, \mathrm{d}, \mathrm{f}, \mathrm{h})$ after $\mathrm{CV}$ experiments; yellow arrows and dashed lines in figure (f) are explained in the text [Zeiss Merlin, acc. volt.: $10 \mathrm{kV}, \mathrm{a}, \mathrm{b}, \mathrm{c}, \mathrm{d}$ : SED; e, f, g, h: In-lens detector].
ICP-OES in the test solutions, indicating that $\mathrm{Cu}$ and $\mathrm{Mn}$ dissolve preferentially compared to $\mathrm{Cr}$. In the case of the material after the $\mathrm{CV}$ experiment, the ICP-OES analysis of the electrolyte indicates a different molar fraction of the dissolved species compared to the chemical corrosion test, more similar to the nominal one. This can be taken as an indication that the corrosion stability of the material changes when the ceramic experiences high enough polarization to trigger $\mathrm{Cr}$ oxidation and subsequent dissolution. The formation of $\mathrm{Cr}(\mathrm{VI})$ on the surface of the ceramic facilitates the dissolution since it can form a very soluble species as $\mathrm{HCrO}_{4}{ }^{-}$. Even if no electrochemical process can be attributed to $\mathrm{Cu}$ from the $\mathrm{CV}$, co-dissolution of $\mathrm{Cu}$ is observed also in the $\mathrm{CV}$ experiments: such dissolution is probably triggered by dissolution of neighboring $\mathrm{Mn}$ and $\mathrm{Cr}$ atoms in the spinel structure. Moreover, Table I reports the absolute and relative mass loss of each metal component calculated from the concentrations determined by ICP-OES. It can be observed that, in addition to the change in molar ratios among the elements between chemical and electrochemical corrosion test, the electrochemical test accounts for a much higher relative dissolution of the components of the ceramic compounds.

\section{Conclusions}

In this study, electrochemical characterization of $\mathrm{MnCu}_{0.25} \mathrm{Cr}_{1.75} \mathrm{O}_{4}$ and $\mathrm{NiCr}_{2} \mathrm{O}_{4}$ has been conducted in acid environment up to $2.0 \mathrm{~V}$ vs SHE. The results indicate that the materials undergo oxidation during the positive going scan, and that dissolution of the oxidized species takes place simultaneously with the oxidation process.

The main conclusions regarding the materials studied can be summarized as follows:

- Both chromite materials exhibit oxidation/dissolution processes which are consistent with the oxidation of $\mathrm{Cr}$ (III) to chromic acid in aqueous acidic environment.

- In the case of Mn-containing chromite, one of the dissolution products can be identified as $\mathrm{MnO}_{4}{ }^{-}$.
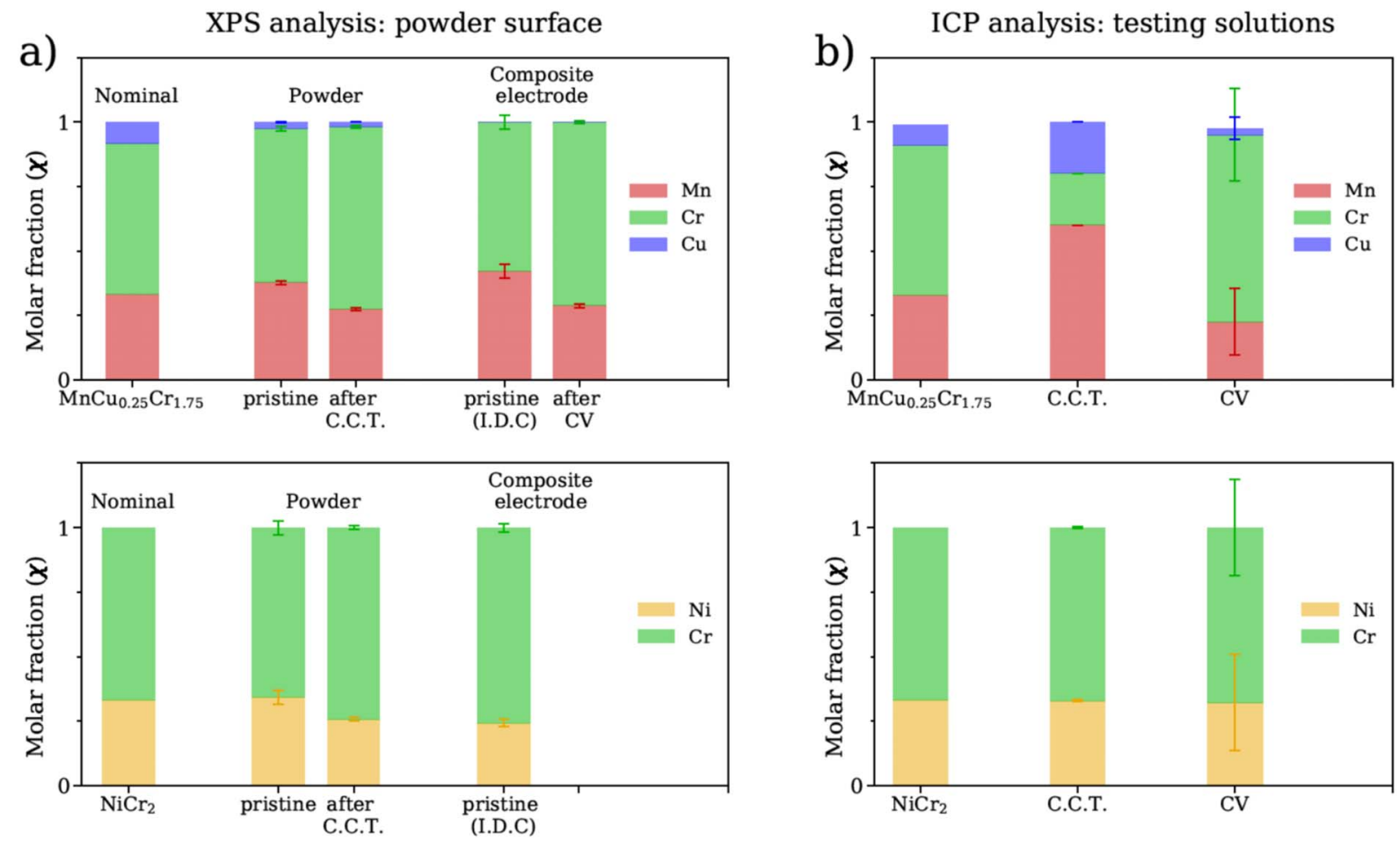

Figure 9. (a) Molar fractions derived from surface analysis by XPS of $\mathrm{MnCu}_{0.25} \mathrm{Cr}_{1.75} \mathrm{O}_{4}$ and $\mathrm{NiCr}_{2} \mathrm{O}_{4}$ as pristine powder, as as-cast composites (I.D.C.: ink-drop casting), after the chemical corrosion test (C.C.T.) and after potential cycling (CV); (b) Molar fractions of the elements found in the testing solutions after C.C.T and $\mathrm{CV}$ determined by ICP-OES; the nominal compositions of the materials are also reported. 
Table I. Absolute and relative dissolved amount of metals determined by ICP-OES after the chemical corrosion test (C.C.T.) and after potential cycling (CV); the starting mass of each metal is calculated from the original sample mass accounting for the mass fraction of each metal.

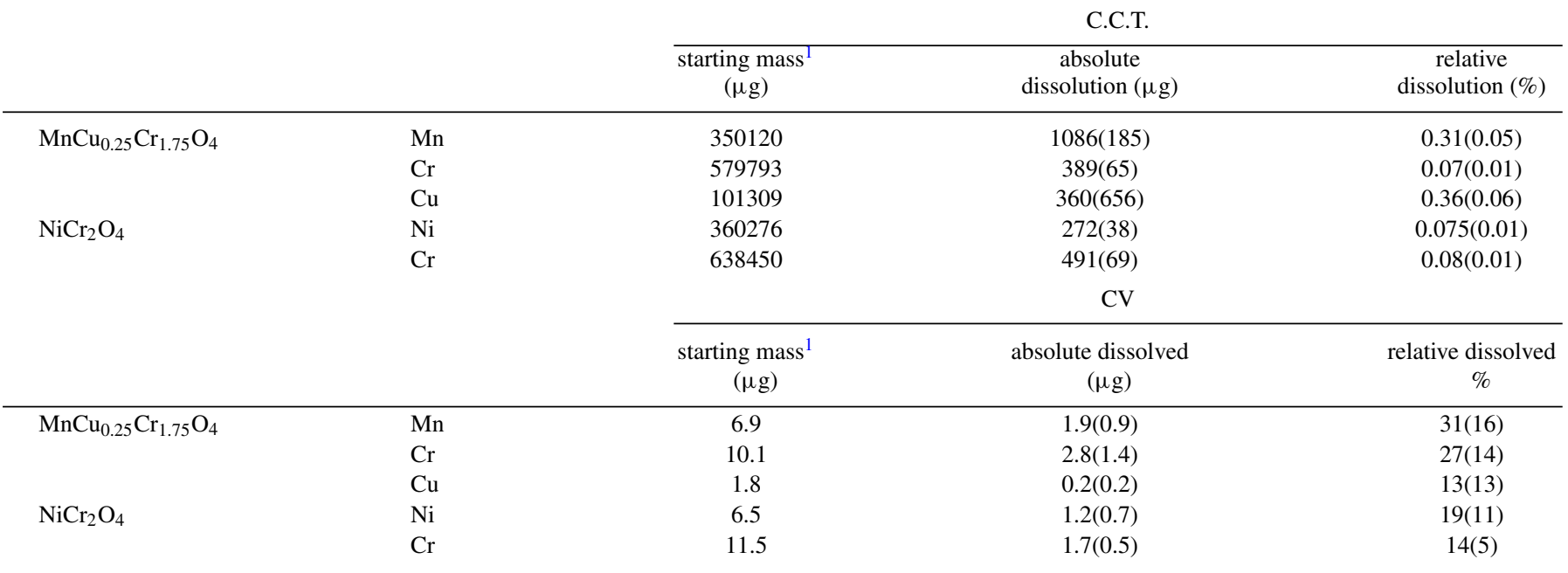

${ }^{1}$ average of at least three samples.

- Based on the experiments conducted in this study, spinel chromites show to undergo oxidation when exposed to potentials larger than $1.25 \mathrm{~V}$ vs SHE. Thus, the spinel chromites are not stable at OER conditions as the OER onset is about $1.4 \mathrm{~V}$ vs. SHE.

This study demonstrates that RRDE measurements can be used to study the dissolution kinetics of $\mathrm{Cr}$ - and $\mathrm{Mn}$ - containing ceramic compounds in aqueous environment: the dissolution of components takes places mainly when the ceramic material experiences oxidation.

As SEM images indicate that the dissolution of the materials is only partial, even after no more electrochemical processes are observed, it may be inferred that the materials become inert to redox processes after the first $\mathrm{CV}$ cycle, but further investigation need to be conducted to determine what is the reason for such inactivity. A possible explanation might be development of a depleted layer on the surface of the particles with a different tendency to oxidation/dissolution compared with the pristine ceramic material.

Further conclusions regarding the elemental analysis conducted on the surface of the materials in the testing solutions can be listed as follows:

- The materials showed enrichment in $\mathrm{Cr}$ on the surface, both after chemical corrosion test and electrochemical characterization.

- The quantification of the species dissolved in the testing solutions indicates that $\mathrm{NiCr}_{2} \mathrm{O}_{4}$ undergoes congruent dissolution both during chemical and electrochemical corrosion.

- $\mathrm{MnCu}_{0.25} \mathrm{Cr}_{1.75} \mathrm{O}_{4}$ leaches $\mathrm{Mn}$ and $\mathrm{Cu}$ preferentially during the chemical corrosion test. Upon electrochemical characterization, the analysis of the testing solution indicates that a larger fraction of $\mathrm{Cr}$ is dissolved. The corrosion properties of the material appear to be strongly influenced by the potential applied: the polarization triggers new dissolution modes.

These results show that a chemical stability toward corrosion does not necessarily correspond to an electrochemical stability; electrochemical characterization of materials is of capital importance for evaluating the behavior in a specific environment, and can deliver fundamental tools for materials design.

\section{Acknowledgments}

This work was funded by Innovation Fund Denmark via e-STORE project, contract no. 4106-00025B. Senior researcher Per Roos is deeply acknowledged for the ICP-OES measurements. Associate professor Johan Hjelm is also acknowledged for the discussions on theoretical and experimental aspects of this work.

\section{ORCID}

Filippo Fenini (D) https://orcid.org/0000-0002-5525-9779

Kent Kammer Hansen (D) https://orcid.org/0000-0002-1349-958X

Mogens Bjerg Mogensen (i) https://orcid.org/0000-0002-0902-0580

\section{References}

1. O. Schmidt et al., Int J Hydrog. Energy, 42, 30470 (2017).

2. L. Bertuccioli et al., Fuel cells and hydrogen Joint undertaking Development of Water Electrolysis in the European Union, Fuel Cells and Hydrogen Joint Undertaking, (2014) https://www.fch.europa.eu/node/783.

3. M. Carmo, D. L. Fritz, J. Mergel, and D. Stolten, Int. J. Hydrog. Energy, 38, 4901 (2013).

4. C. Rakousky, G. P. Keeley, K. Wippermann, M. Carmo, and D. Stolten, Electrochim Acta, 278, 324 (2018).

5. H. S. Oh et al., J. Am. Chem. Soc., 138, 12552 (2016).

6. W. Sun, Z. Zhou, W. Q. Zaman, L. Cao, and J. Yang, ACS Appl. Mater. Interfaces, 9 , 41855 (2017).

7. S. Geiger et al., ChemSusChem, 10, 4140 (2017)

8. H.-S. Oh, H. N. Nong, T. Reier, M. Gliech, and P. Strasser, Chem. Sci., 6, 3321 (2015).

9. N. F. Asri, T. Husaini, A. B. Sulong, E. H. Majlan, and W. R. W. Daud, Int. J. Hydrog. Energy, 42, 9135 (2017).

10. S. Lædre, O. E. Kongstein, A. Oedegaard, H. Karoliussen, and F. Seland, Int. J. Hydrog. Energy, 1 (2017).

11. P. Lettenmeier et al., J. Electrochem. Soc., 163, F3119 (2016).

12. A. S. Gago et al., J. Power Sources, 307, 815 (2016).

13. L. V. Morozova and V. P. Popov, Glass Phys. Chem., 36, 86 (2010).

14. A. Petric and H. Ling, J Am Ceram Soc, 90, 1515 (2007).

15. Z. Lu, J. Zhu, E. Andrew Payzant, and M. P. Paranthaman, JAm Ceram Soc, 88, 1050 (2005).

16. E. Stefan and J. T. S. Irvine, J. Mater. Sci., 46, 7191 (2011).

17. E. Stefan, G. Tsekouras, and J. T. S. Irvine, Adv Energy Mater, 3, 1454 (2013).

18. E. Stefan, P. a. Connor, and J. T. S. Irvine, J Mater Chem A, 1, 8262 (2013).

19. C. F. Cheng, Corrosion, 20, 341t (1964).

20. B. Stellwag, Corros Sci, 40, 337 (1998).

21. V. A. Kurepin, D. A. Kulik, A. Hiltpold, and M. Nicolet, Thermodynamic modelling of $\mathrm{Fe}$-Cr-Ni spinel formation at the light-water reactor conditions, p. 4, Paul Scherrer Institut, Laboratory for Material Research [and] Waste Management Laboratory, (2002) http://agris.fao.org/agris-search/search.do?recordID=US201300072408.

22. A. La Fontaine, H. W. Yen, P. J. Felfer, S. P. Ringer, and J. M. Cairney, Scr Mater, 99, 1 (2015)

23. Q. Zhao, C. jun Liu, B. kuan Li, and M. fa Jiang, Int J Min. Met. Mater, 24, 1361 (2017).

24. F. Fenini, K. K. Hansen, C. Savaniu, J. T. S. Irvine, and M. B. Mogensen, ECS Trans., 85, 65 (2018). 
25. A. B. Alonso Sedano, M. L. Tascón Garciá, M. D. Vázquez Barbado, and P. Sánchez Batanero, J. Electroanal. Chem., 566, 433 (2004).

26. T. Grygar, S. Bakardjieva, P. Bezdicka, and P. Vorm, Ceram. - Silik., 45, 55 (2001).

27. T. Grygar and P. Bezdička, J. Solid State Electrochem., 3, 31 (1998).

28. A. J. Bard, R. Parsons, and J. Jordan, Standard potentials in aqueous solution, International Union of Pure and Applied Chemistry, (1985).

29. E. B. Godunov, A. D. Izotov, and I. G. Gorichev, Inorg. Mater, 53, 831 (2017).

30. S. Bakardjieva, P. Bezdička, T. Grygar, and P. Vorm, J Solid State Electrochem, 4, $306(2000)$.

31. K. Lohbeck, H. Haferkorn, W. Fuhrmann, and N. Fedtke, Ullmann's Encyclopedia of Industrial Chemistry, 22, 223 (2012).

32. T. Okabe, E. Narita, Y. Kobayashi, and M. Mita, (1976) https://patents.google.com/ patent/US3986941A/en.

33. J. R. Rumble ed., CRC Handbook of Chemistry and Physics, 99th Edition (Internet Version 2018)., CRC Press/Taylor \& Francis, Boca Raton, FL http://hbcponline.com/ faces/contents/ContentsSearch.xhtml.

34. D. Yohe, A. Riga, R. Greef, and E. Yeager, Electrochimica Acta, 13, 1351 (1968).

35. M. Bonomo, G. Naponiello, and D. Dini, J. Electroanal. Chem., 816, 205 (2018).

36. R. Supadanaison et al., Mater. Today Proc., 5, 14896 (2018).

37. M. Melník and M. Kabešová, J. Coord. Chem., 50, 323 (2000).
38. F. Fenini, K. K. Hansen, and M. B. Mogensen, in preparation.

39. Y. Garsany, O. A. Baturina, K. E. Swider-Lyons, and S. S. Kocha, Anal. Chem., 82, $6321(2010)$.

40. F. Scholz and B. Lange, Trends Anal Chem, 11, 359 (1992).

41. T. Grygar, F. Marken, U. Schröder, and F. Scholz, Collect. Czechoslov. Chem. Commun., 67, 163 (2002).

42. L. Wang et al., Nano Energy, 34, 385 (2017).

43. Y. Lee, J. Suntivich, K. J. May, E. E. Perry, and Y. Shao-Horn, J Phys Chem Lett, 399 (2012).

44. J. Suntivich, K. J. May, H. A. Gasteiger, J. B. Goodenough, and Y. Shao-Horn, Sci. $80-$, 334, 1383 (2011)

45. R. Frydendal et al., ChemElectroChem, 1, 2075 (2014).

46. C. Wei et al., Adv. Mater, 29, 1606800 (2017).

47. Y. Yi et al., Catal. Today, 295, 32 (2017).

48. J. O. Besenhard, P. Minderer, and M. Bindl, Synth Met, 34, 133 (1989).

49. M. Huynh, D. K. Bediako, and D. G. Nocera, J. Am. Chem. Soc., 136, 6002 (2014).

50. M. Huynh, C. Shi, S. J. L. Billinge, and D. G. Nocera, J. Am. Chem. Soc., 137, 14887 (2015).

51. N. Danilovic et al., J Phys Chem Lett, 5, 2474 (2014).

52. S. Cherevko, J. Electroanal. Chem., 787, 11 (2017). 